\title{
An Indo-Mediterranean diet was more effective than a control diet in primary and secondary coronary artery disease prevention
}

Singh RB,Dubnov G, Niaz MA, et al. Effect of an Indo-Mediterranean diet on progression of coronary artery disease in high risk patients (Indo-Mediterranean Diet Heart Study): a randomised single-blind trial. Lancet 2002;360:1455-61.

QUESTION: In patients with, or at high risk for, coronary artery disease (CAD), is an Indo-Mediterranean diet more effective than the conventional step 1 National Cholesterol Education Program (NCEP) prudent diet?

Design

Randomised (unclear allocation concealment*), blinded \{clinicians, data collectors, and outcome assessors $\} \dagger^{* *}$ controlled trial with 2 years of follow up.

\section{Setting}

Moradabad, India.

\section{Patients}

1000 patients $>25$ years of age (mean age $48.5 \mathrm{y}, 90 \%$ men) with angina pectoris, myocardial infarction, or $\geq 1$ major risk factor for $\mathrm{CAD}$, recruited through advertising. Exclusion criteria included cancer, long term diarrhoea or dysentery, blood urea nitrogen concentrations $>6.6 \mathrm{mmol} / \mathrm{l}$, and arthritis. Follow up was $98 \%$.

\section{Intervention}

Participants were allocated to an Indo-Mediterranean $\operatorname{diet}(\mathrm{n}=499)$ or a control diet similar to the step 1 NCEP prudent diet $(\mathrm{n}=501)$. Patients in both groups were advised to walk briskly $\geq 3-4 \mathrm{~km} /$ day or jog intermittently for $\geq 10-15$ minutes/d.

\section{Main outcome measures}

Fatal or nonfatal myocardial infarction (MI), sudden cardiac death, and total cardiac endpoints (combined total of MI and sudden cardiac death).

Source of funding: no external funding.

For correspondence: Professor E M Berry, Braun School of Public Health, and Hebrew University-Hadassah Medical School, Jerusalem, Israel. berry@md.huji.ac.il.

Abstract and commentary also appear in ACP Journal Club.

\section{Main results}

Analysis was by intention to treat. At 2 years, patients who were on the Indo-Mediterranean diet consumed more fruits, vegetables, nuts, and legumes (mean $573 v$ $231 \mathrm{~g} / \mathrm{d}, \mathrm{p}<0.001$ ), consumed more n-3 fatty acids (mean 1.8 v $0.78 \mathrm{~g} / \mathrm{d}, \mathrm{p}<0.001$ ), and had lower serum cholesterol concentrations (mean $5.04 v 5.59 \mathrm{mmol} / \mathrm{l}$, $\mathrm{p}<0.001)$ than did patients on the control diet. The Indo-Mediterranean diet group had lower rates of all endpoints except fatal MI (table).

Indo-Mediterranean (Indo-Medit) diet v control diet for coronary artery disease $\$$

\begin{tabular}{lllll}
$\begin{array}{c}\text { Outcomes at } 2 \\
\text { years }\end{array}$ & Indo-Medit & Control & $\begin{array}{l}\text { Adjusted RRR } \\
(\mathbf{9 5 \%} \mathrm{Cl}) \S\end{array}$ & $\begin{array}{l}\text { Unadjusted NNT } \\
\text { (Cl) }\end{array}$ \\
\hline Nonfatal MI & $4.2 \%$ & $8.6 \%$ & $53 \%(21$ to 72$)$ & $23(13$ to 73$)$ \\
\hline Fatal MI & $2.4 \%$ & $3.4 \%$ & $33 \%(-42$ to 69$)$ & Not significant \\
\hline $\begin{array}{c}\text { Sudden cardiac } \\
\text { death }\end{array}$ & $1.2 \%$ & $3.2 \%$ & $67 \%(14$ to 87$)$ & $50(25$ to 533$)$ \\
\hline $\begin{array}{c}\text { Total cardiac } \\
\text { endpoints }\end{array}$ & $7.8 \%$ & $15.2 \%$ & $52 \%(29$ to 67$)$ & $14(9$ to 29$)$ \\
\hline
\end{tabular}

\section{Conclusion}

In patients with, or at high risk for, coronary artery disease (CAD), an Indo-Mediterranean diet was more effective in primary and secondary prevention of CAD than the conventional step 1 National Cholesterol Education Program prudent diet.

*See glossary.

$\dagger$ Information provided by author.

\section{COMIMENTARY}

The study by Singh $e t$ al shows that an Indo-Mediterranean diet combined with intensive nutritional counselling is clinically beneficial in high risk patients. The results add to the Lyon Diet Heart Study, which used a Mediterranean diet, showing that non-pharmacological intervention can lead to reductions in cardiovascular endpoints. ${ }^{1}$ The IndoMediterranean diet differs from the Mediterranean diet because fish, rapeseed, and olive oils are replaced by mustard or soybean oils, green leafy vegetables, certain nuts, and whole grains.

Although this study is well done, a few caveats should be noted. Firstly, the treatment group differed from the control group in both diet and intensity of nutritional counselling. It is unclear which of these factors accounted for the difference in outcomes. Secondly, the step I diet has been phased out of the 2001 National Cholesterol Education Program (NCEP); Adult Treatment Panel $\mathrm{III}^{2}$ recommendations favour a more stringent step 2 diet, now called therapeutic lifestyle changes (TLC). The Indo-Mediterranean diet was not compared with the TLC diet. Thirdly, the study patient group was a homogenous population of urban Indians, therefore generalisation to North Americans or Europeans is questionable. The population studied was considered high risk. The beneficial effects may be less dramatic in lower risk populations. Also, this was a single blind trial and bias may have occurred among participants and treating physicians. Finally, compliance with this diet may be difficult in a nonvegetarian population.

This study may provide another diet choice to reduce cardiac risk. In defining future practice, it would be important to compare the Indo-Mediterranean diet to the TLC diet with equal counselling in each group.

Meera Jain, MD

Mark Rosenberg, MD Providence Portland Medical Center

Portland Oregon

1 De Lorgeril M, Salen P, Martin JL, et al. Mediterranean diet, traditional risk factors, and rate of cardiovascular complicaions after myocardial infarction: final report of the Lyon Diet Heart Study. Circulation 1999;99:779-85.

2 Executive Summary of the Third Report of the National Cholesterol Education Program (NCEP) Expert Panel on Detection, Evaluation, and Treatment of High Blood Choleserol in Adults (Adult Treatment Panel III). JAMA 2001;285:2486-97. 